\title{
Long-term palmitic acid supplementation interacts with parity in lactating dairy cows: Production responses, nutrient digestibility, and energy partitioning
}

\author{
J. de Souza and A. L. Lock ${ }^{1}$ \\ Department of Animal Science, Michigan State University, East Lansing 48824
}

\begin{abstract}
The objective of our study was to evaluate the effects of long-term palmitic acid (C16:0) supplementation and parity on production, nutrient digestibility, and energy partitioning of mid-lactation dairy cows. Forty mid-lactation Holstein cows (18 primiparous and 22 multiparous) were used in a block design. Cows were assigned to receive either a control diet containing no supplemental fat $(\mathrm{CON})$ or a $\mathrm{C} 16: 0$-enriched supplemented diet (PA; 1.5\% diet dry matter) fed for $10 \mathrm{wk}$. Compared with CON, PA increased dry matter intake, milk yield, cumulative milk yield, milk fat content, milk fat yield, 16-carbon milk fatty acid (FA) yield, 3.5\% fatcorrected milk yield, and energy-corrected milk yield. Additionally, PA increased body weight change, but did not affect body condition score change compared with CON. A tendency for a treatment by parity interaction was observed for milk yield due to PA increasing milk yield in multiparous but not in primiparous cows. In addition, we observed interactions between treatment and parity for fat-corrected milk, energy-corrected milk, and milk fat yield due to PA increasing these variables to a greater extent in multiparous compared with primiparous cows. Interestingly, we observed an interaction between treatment and parity for body weight change, due to PA increasing body weight change in primiparous but not in multiparous cows. The PA treatment increased dry matter and neutral detergent fiber digestibilities compared with CON. Although PA did not affect 18-carbon FA digestibility, compared with CON, PA decreased 16-carbon and total FA digestibilities and increased total FA intake by $470 \mathrm{~g} / \mathrm{d}$ and absorbed total FA by $316 \mathrm{~g} / \mathrm{d}$. We also observed an interaction between treatment and parity for total absorbed FA due to PA increasing it to a greater extent in multiparous than in primiparous cows. Compared with CON, PA increased apparent energy intake and milk energy out-
\end{abstract}

Received October 5, 2017.

Accepted December 4, 2017.

${ }^{1}$ Corresponding author: allock@msu.edu put. We observed an interaction between treatment and parity for milk energy output due to PA increasing milk energy output to a greater extent in multiparous than primiparous cows. Additionally, an interaction between treatment and parity was observed for energy output in body reserves due to PA increasing energy output in body reserves in primiparous but not in multiparous cows. In conclusion, production responses of dairy cows to PA were consistent throughout the 10-wk treatment period. In addition, PA supplementation interacted with parity, with production responses increased to a greater extent in multiparous than primiparous cows and energy partitioned to body reserves only increased in primiparous cows.

Key words: palmitic acid, milk fat, digestibility, partitioning

\section{INTRODUCTION}

Fat supplements are commonly added to dairy cow diets to increase dietary energy density, feed efficiency, the yields of milk and milk fat, and to improve energy balance (Palmquist, 1994; Rabiee et al., 2012). Recently, considerable research has focused on palmitic acid (C16:0) because of its potential to increase milk fat concentration and yield, and the efficiency of milk production compared with a control diet (Lock et al., 2013; de Souza et al., 2018) and with other FA supplements (Rico et al., 2014a,b). However, our research, and work by others, has been conducted mostly in changeover design experiments (i.e., crossover and Latin squares) with production and metabolic responses evaluated during short-term feeding (maximum of 21-d feeding periods). This raises a question about the consistency of the response under long-term conditions. Recently, Mathews et al. (2016) observed that long-term feeding (7 wk) of mid-lactation cows with C16:0 (3.9\% of diet DM) increased the yield of milk and milk components without suppressing DMI, relative to no added fat supplementation. Considering that most dairy farms that use supplemental fat would include it in diets within the range of 0.5 to $2.5 \%$ of ration DM (Rico et 
al., 2017), the determination of long-term C16:0 feeding within this range has important implications.

Variation in response to C16:0 supplementation has also been reported. Previous studies have observed that C16:0 supplementation decreased DMI (Lock et al., 2013; Rico et al., 2014a), increased DMI (Mosley et al., 2007), or did not affect DMI (Piantoni et al., 2013; de Souza et al., 2017b, 2018) compared with a control diet. Additionally, milk yield responses have also varied with some studies reporting no effect of C16:0 on milk yield (Lock et al., 2013; Rico et al., 2014a), whereas others observed increases in milk yield (Mosley et al., 2007; Piantoni et al., 2013). The observed variations when using a C16:0-enriched supplement suggest that other dietary or animal factors interact with fatty acid (FA) supplementation in altering dairy cow responses. One possible animal factor that may interact with fat supplementation is parity, but results have been inconsistent (Holter et al., 1992; Drackley et al., 2003). Holter et al. (1992) observed that milk yield increased in primiparous but not in multiparous cows when Casalts of palm FA were fed for 16 wk. Conversely, Drackley et al. (2003) did not observe interactions between parity and white grease supplementation ( $3 \%$ diet DM) on production responses of mid-lactation cows. The differences in milk yield response and energy partitioning in primiparous compared with multiparous cows to supplemental fat may be due to primiparous cows having additional energy requirements for growth as well as for milk production (Grummer et al., 1995). To our knowledge, no reports in the current literature have evaluated whether primiparous and multiparous cows would respond differently to C16:0 supplementation.

Therefore, the objective of our study was to evaluate the effects of long-term C16:0 supplementation and parity on yield of milk and milk components, and nutrient digestibility of mid-lactation dairy cows. We hypothesized that long-term feeding of a C16:0-enriched supplement would consistently increase production responses of mid-lactation cows. Also, we postulated that production responses of multiparous cows would be greater than primiparous cows due to primiparous cows having additional energy requirements for growth.

\section{MATERIALS AND METHODS}

\section{Design and Treatment Diets}

Experimental procedures were approved by the Institutional Animal Care and Use Committee at Michigan State University. Forty mid-lactation Holstein cows, 18 primiparous and 22 multiparous, averaging (mean \pm SD) $136 \pm 45$ and $144 \pm 44$ DIM, $41.5 \pm 4.9$ and 52.1 $\pm 5.9 \mathrm{~kg}$ of milk, and $3.19 \pm 0.21$ and $3.02 \pm 0.25 \mathrm{BCS}$, respectively, from the Michigan State University Dairy Field Laboratory were used in a complete randomized block design. All animals received a common diet with no fat supplementation during a 14-d preliminary period to obtain baseline values. Cows were blocked by parity (primiparous vs. multiparous) milk yield (up to $1.2 \mathrm{~kg}$ difference) and BCS (up to 0.5-unit difference). Cows received either a control diet containing no supplemental fat $(\mathbf{C O N})$ or a C16:0-enriched supplemented diet (PA; $1.5 \%$ diet DM;) fed for $10 \mathrm{wk}$. The PA supplement was a free FA product of high purity, contained approximately 81\% C16:0 and 97\% total FA, and replaced soyhulls in the diet. Diets were formulated to meet the requirements of the average cow in the group (NRC, 2001; Table 1). After the supplementation period, all cows received the CON diet for $2 \mathrm{wk}$ to evaluate carryover effects. Dry matter concentration of forages was determined twice weekly and diets were adjusted when necessary. Throughout the experiment cows were housed in individual tie stalls. Access to feed was blocked daily from 1000 to $1200 \mathrm{~h}$ to allow for the collection of orts and offering feed. Cows were fed $115 \%$ of expected intake daily, and feed intake was recorded. Water was available ad libitum in each stall and stalls were bedded with sawdust and cleaned twice per day.

\section{Data and Sample Collection}

Milk yield and feed offered and refused were recorded daily throughout the experiment and averaged by week for further analysis. Samples of all diet ingredients $(0.5$ $\mathrm{kg})$ and orts from each cow $(\sim 12.5 \%)$ were collected weekly during the entire experiment and stored in plastic bags at $-20^{\circ} \mathrm{C}$ until processing. On d 63 (wk 9), fecal samples $(500 \mathrm{~g})$ were collected every $6 \mathrm{~h}$, representing every $6 \mathrm{~h}$ of a 24 -h period to account for diurnal variation, for nutrient digestibility analysis. Feces were stored in a sealed plastic cup at $-20^{\circ} \mathrm{C}$ until dried. Blood samples $(\sim 15 \mathrm{~mL})$ were collected by venipuncture of coccygeal vessels within $1 \mathrm{~h}$ before feeding on d 21, 42, and 63 of the study and stored on ice until centrifugation at $2,000 \times g$ for $15 \mathrm{~min}$ at $4^{\circ} \mathrm{C}$ (within 30 min of sample collection). Plasma was transferred into microcentrifuge tubes and stored at $-20^{\circ} \mathrm{C}$. Throughout the experiment, milk samples were collected twice a week at each milking and stored with preservative at $4^{\circ} \mathrm{C}$ for component analysis (Universal Lab Services, East Lansing, MI). An additional milk sample was collected at each milking on d 21,42, and 63 of the study and stored without preservative at $-20^{\circ} \mathrm{C}$ for determination of FA profile. Body weight measurements were taken 3 times per week following the afternoon milking, 
and BW change was calculated according to Boerman et al. (2015b). Body condition was scored weekly by 3 trained investigators on a 5 -point scale, in 0.25 -unit increments, where $1=$ thin and $5=$ fat, as described by Wildman et al. (1982).

\section{Sample Analysis}

Diet ingredients, orts, and fecal samples were dried at $55^{\circ} \mathrm{C}$ in a forced-air oven for $72 \mathrm{~h}$ for $\mathrm{DM}$ determination. Dried samples were ground with a Wiley mill (1-mm screen; Arthur H. Thomas, Philadelphia, PA). Feed ingredients, orts, and feces were analyzed for NDF, CP, and starch concentration as described by Boerman et al. (2015b). Fatty acid concentrations in feed ingredients, orts, and feces were determined as described by Lock et al. (2013). Gross energy was assayed by bomb calorimeter (Parr Instrument Inc., Moline,

Table 1. Ingredient and nutrient composition of treatment diets

\begin{tabular}{|c|c|c|}
\hline \multirow[b]{2}{*}{ Item } & \multicolumn{2}{|c|}{ Treatment $^{1}$} \\
\hline & $\mathrm{CON}$ & PA \\
\hline \multicolumn{3}{|l|}{ Ingredient, \% DM } \\
\hline Corn silage & 23.9 & 23.9 \\
\hline Alfalfa silage & 17.7 & 17.7 \\
\hline Wheat straw & 2.82 & 2.82 \\
\hline Ground corn & 15.9 & 15.9 \\
\hline High-moisture corn & 14.5 & 14.5 \\
\hline Soybean meal & 12.1 & 12.1 \\
\hline Soyhulls & 5.57 & 4.06 \\
\hline Whole cottonseed & 4.28 & 4.28 \\
\hline Palmitic acid supplement $^{2}$ & - & 1.51 \\
\hline Mineral and vitamin $\operatorname{mix}^{3}$ & 1.92 & 1.92 \\
\hline Limestone & 0.60 & 0.60 \\
\hline Sodium bicarbonate & 0.71 & 0.71 \\
\hline \multicolumn{3}{|c|}{ Nutrient composition, ${ }^{4} \%$ of DM } \\
\hline $\mathrm{NDF}$ & 30.9 & 29.9 \\
\hline Forage NDF & 19.0 & 19.0 \\
\hline $\mathrm{CP}$ & 16.7 & 16.5 \\
\hline Starch & 26.4 & 26.3 \\
\hline Fatty acids & 3.36 & 4.85 \\
\hline $16: 0$ & 0.58 & 1.77 \\
\hline 18:0 & 0.12 & 0.21 \\
\hline cis-9 18:1 & 0.63 & 0.76 \\
\hline cis-9, cis-12 18:2 & 1.65 & 1.67 \\
\hline cis-9, cis-12, cis-15 18:3 & 0.22 & 0.22 \\
\hline
\end{tabular}

${ }^{1} \mathrm{CON}=$ control diet; $\mathrm{PA}=1.5 \%$ of $\mathrm{C} 16: 0$-enriched fatty acid supplement replacing soyhulls.

${ }^{2}$ C16:0-enriched fatty acid supplement (Magnafat, Energy Feeds International, Lago Vista, TX). The supplement contained $97.0 \%$ total fatty acids and (g/100 g of fatty acids) 1.0 of C14:0, 81.1 of C16:0, 3.7 of C18:0, 8.9 of cis-9 C18:1.

${ }^{3}$ Vitamin and mineral mix contained $34.1 \%$ dry ground shelled corn, $25.6 \%$ white salt, $21.8 \%$ calcium carbonate, $9.1 \%$ Biofos (The Mosaic Co., Plymouth, MN), 3.9\% magnesium oxide, $2 \%$ soybean oil, and $<1 \%$ of each of the following: manganese sulfate, zinc sulfate, ferrous sulfate, copper sulfate, iodine, cobalt carbonate, vitamin E, vitamin A, vitamin $\mathrm{D}$, and selenium.

${ }^{4}$ Expressed as percent of as fed.
IL). Indigestible NDF was used as an internal marker to estimate fecal output to determine apparent totaltract digestibility of nutrients (Cochran et al., 1986). Indigestible NDF was estimated as NDF after a 240-h in vitro fermentation (Van Soest et al., 1991).

Milk samples were analyzed for fat, true protein, and lactose concentrations by mid-infrared spectroscopy (AOAC, 1990; method 972.160, Universal Lab Services, Lansing, MI). Yields of 3.5\% FCM, milk energy, and milk components were calculated using milk yield and component concentrations from each milking, summed for a daily total, and averaged for each week. Milk samples used for analysis of FA composition were composited based on milk fat yield. Milk lipids were extracted, and FAME prepared and quantified using GLC according to Lock et al. (2013). Yield of individual FA (g/d) in milk fat were calculated by using milk fat yield and FA concentration to determine yield on a mass basis using the molecular weight of each FA while correcting for glycerol content and other milk lipid classes (Piantoni et al., 2013).

Data were used to calculate milk energy output and body reserves throughout each treatment period. Energy intake was calculated according to Harvatine and Allen (2006) using equations (NRC, 2001). Digestible energy $(\mathbf{D E})$ intake $=$ gross energy $(\mathbf{G E})$ intake $\times$ GE digestibility; $\mathrm{ME}$ and $\mathrm{NE}_{\mathrm{L}}$ intake were calculated from DE according to NRC (2001). Energy output was calculated according to Harvatine and Allen (2006). Milk energy output (Mcal/d) was calculated according to NRC (2001) as milk energy output (Mcal/d) $=[9.29$ $\times$ fat $(\mathrm{kg})+5.63 \times$ true protein $(\mathrm{kg})+3.95 \times$ lactose $(\mathrm{kg})]$. Mean daily BW change $(\mathrm{kg} / \mathrm{d})$ was calculated for each cow within period by linear regression after 2 iterations of removing outliers. Energy output in body reserves (Mcal/d) was estimated according to NRC $(2001)$ as body reserves $(\mathrm{Mcal} / \mathrm{d})=[(2.88+1.036$ $\times \mathrm{BCS}) \times \Delta \mathrm{BW}]$, where $\mathrm{BCS}$ was the average $\mathrm{BCS}$ for the study and $\triangle B W$ was $B W$ change. Energy for maintenance (Mcal/d) was the difference between the energy intake and energy allocated to milk and BW.

All plasma samples were analyzed using an Olympus AU640e chemistry analyzer (Olympus America, Center Valley, PA) at the Diagnostic Center for Population and Animal Health of Michigan State University (Lansing, MI).

\section{Statistical Analysis}

All production and milk FA data were analyzed using the mixed model procedure of SAS (version 9.4, SAS Institute Inc., Cary, NC) according to the following model with repeated measures: 


$$
\begin{aligned}
& \mathrm{Y}_{\mathrm{ijklm}}=\mu+\mathrm{F}_{\mathrm{i}}+\mathrm{T}_{\mathrm{j}}+\mathrm{P}_{\mathrm{k}}+\mathrm{B}_{\mathrm{l}}+\mathrm{C}_{\mathrm{m}}\left(\mathrm{P}_{\mathrm{k},} \mathrm{B}_{\mathrm{l}}\right)+\mathrm{F}_{\mathrm{i}} \\
& \times \mathrm{T}_{\mathrm{j}}+\mathrm{F}_{\mathrm{i}} \times \mathrm{P}_{\mathrm{k}}+\mathrm{T}_{\mathrm{j}} \times \mathrm{P}_{\mathrm{k}}+\mathrm{F}_{\mathrm{i}} \times \mathrm{T}_{\mathrm{j}} \times \mathrm{P}_{\mathrm{k}}+\mathrm{e}_{\mathrm{ijklm}},
\end{aligned}
$$

where $\mathrm{Y}_{\mathrm{ijklm}}=$ the dependent variable, $\mu=$ the overall mean, $F_{i}=$ the fixed effect of treatment, $T_{j}=$ the fixed effect of time, $\mathrm{P}_{\mathrm{k}}=$ the fixed effect of parity, $\mathrm{B}_{1}=$ the random effect of block, $\mathrm{C}_{\mathrm{m}}=$ the random effect of cow nested in block and parity, $F_{i} \times T_{j}=$ the fixed effect of interaction between treatment and time, $F_{i} \times$ $\mathrm{P}_{\mathrm{k}}=$ the fixed effect of interaction between treatment and parity, $\mathrm{T}_{\mathrm{j}} \times \mathrm{P}_{\mathrm{k}}=$ the fixed effect of interaction between time and parity, $F_{i} \times T_{j} \times P_{k}=$ the fixed effect of interaction between treatment, time and parity, and $\mathrm{e}_{\mathrm{ijklm}}=$ the residual error. Unless otherwise specified, first-order autoregressive was the covariate structure used for analysis because it resulted in the lowest Bayesian information criterion for most of the variables measured. Cumulative milk yield, nutrient digestibility, and energy partitioning data were analyzed using a reduced model without the main effect of time and interactions between time and treatment and time and parity. Normality of the residuals was checked with normal probability and box plots and homogeneity of variances with plots of residuals versus predicted values. Interactions were evaluated, but removed from the statistical model when not significant $(P>0.20)$. Main effects were declared significant at $P \leq 0.05$, and tendencies were declared at $0.05<P \leq 0.10$. Interactions were declared significant at $P \leq 0.10$, and tendencies were declared at $0.10<P \leq 0.15$.

\section{RESULTS}

\section{Production Responses}

Compared with CON, PA increased DMI, milk yield, cumulative milk yield milk fat content, milk fat yield, 3.5\% FCM, and ECM compared with CON (all $P<0.05$; Table 2). Also, PA tended to increase milk protein yield $(P=0.06)$ and milk lactose yield $(P=$ 0.06) compared with CON. Additionally, PA increased BW change $(P=0.01)$ compared with CON. No treatment differences were observed in the concentrations of protein and lactose as well as in BW, BCS, or feed efficiency (all $P>0.10$ ). We observed a tendency for an interaction between treatment and time for DMI $(P=0.15)$ due to PA increasing DMI after wk 1 of supplementation (Figure 1A). A treatment by time interaction was observed for milk yield $(P=0.03)$ due to PA increasing milk yield after wk 1 of supplementation (Figure 1B). We observed a tendency of an interaction between treatment and time for $\operatorname{ECM}(P=0.13)$ due to PA consistently increased ECM after wk 2 (Figure 1C). We also observed interactions between treatment and time for milk protein yield $(P<0.01)$, milk lactose yield $(P=0.04)$, and ECM:feed ratio $(P<0.01)$ due to PA also consistently increasing these variables after wk 2 .

Table 2. Milk production, milk composition, BW, and BCS for cows fed treatment diets over the 10-wk treatment period $(\mathrm{n}=39)$

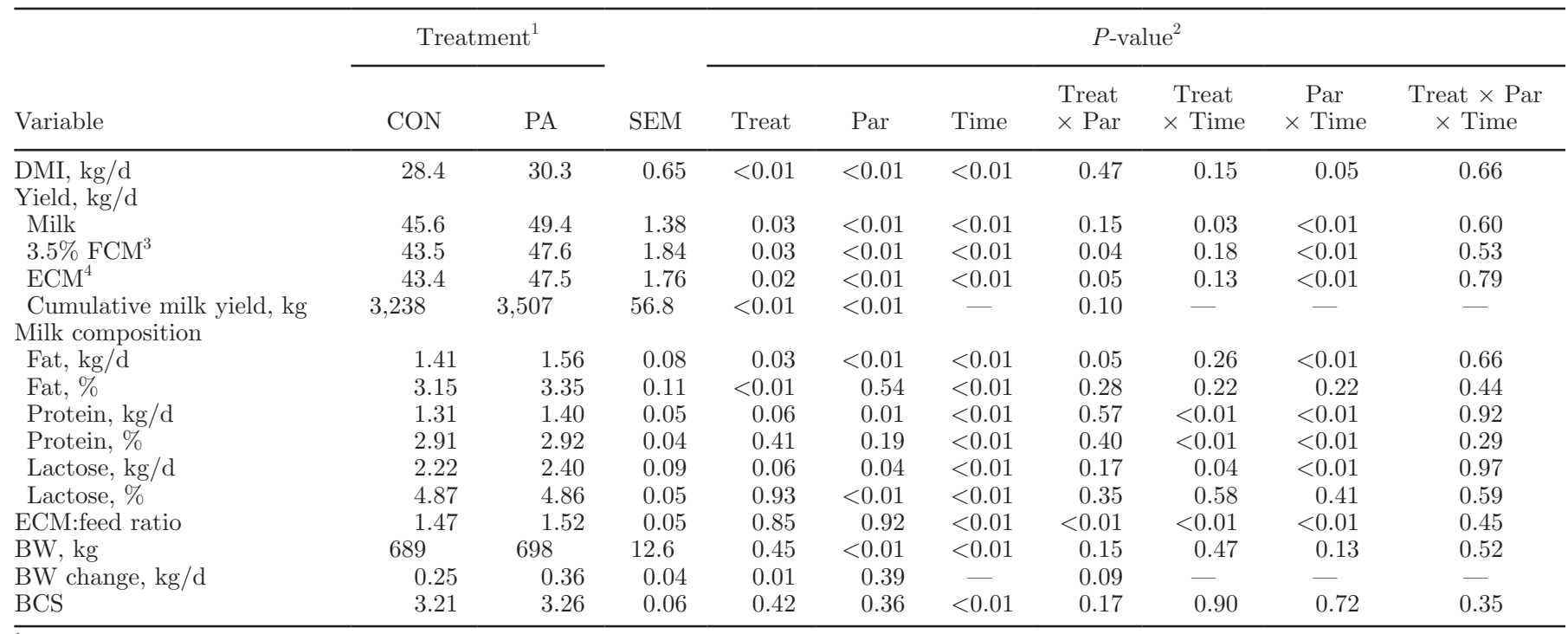

${ }^{1} \mathrm{CON}=$ control diet; $\mathrm{PA}=1.5 \%$ of $\mathrm{C} 16: 0$-enriched fatty acid supplement replacing soyhulls.

${ }^{2} P$-values refer to the ANOVA results for the main effects of treatment (Treat), parity (Par), time, and their interactions.

${ }^{3} 3.5 \% \mathrm{FCM}=[(0.4324 \times \mathrm{kg}$ of milk $)+(16.216 \times \mathrm{kg}$ of milk fat $)]$.

${ }^{4} \mathrm{ECM}=[(0.327 \times \mathrm{kg}$ of milk $)+(12.95 \times \mathrm{kg}$ of milk fat $)+(7.20 \times \mathrm{kg}$ of milk protein $)]$. 
We observed a tendency for a treatment by parity interaction for milk yield $(P=0.15)$ due to PA increasing milk yield in multiparous but not primiparous cows compared with CON (Figure 2A). The PA treatment increased FCM (interaction $P=0.04$; Figure 2B), ECM (interaction $P=0.05$; Figure $2 \mathrm{C}$ ), and milk fat yield (interaction $P=0.05$; Figure 2D) compared with CON to a greater extent in multiparous compared with primiparous cows. Additionally, ECM:feed ratio decreased with PA compared with CON in primiparous cows, but increased with PA in multiparous cows (interaction $P<0.01$; Figure 2E). Interestingly, we observed an interaction between treatment and parity for BW
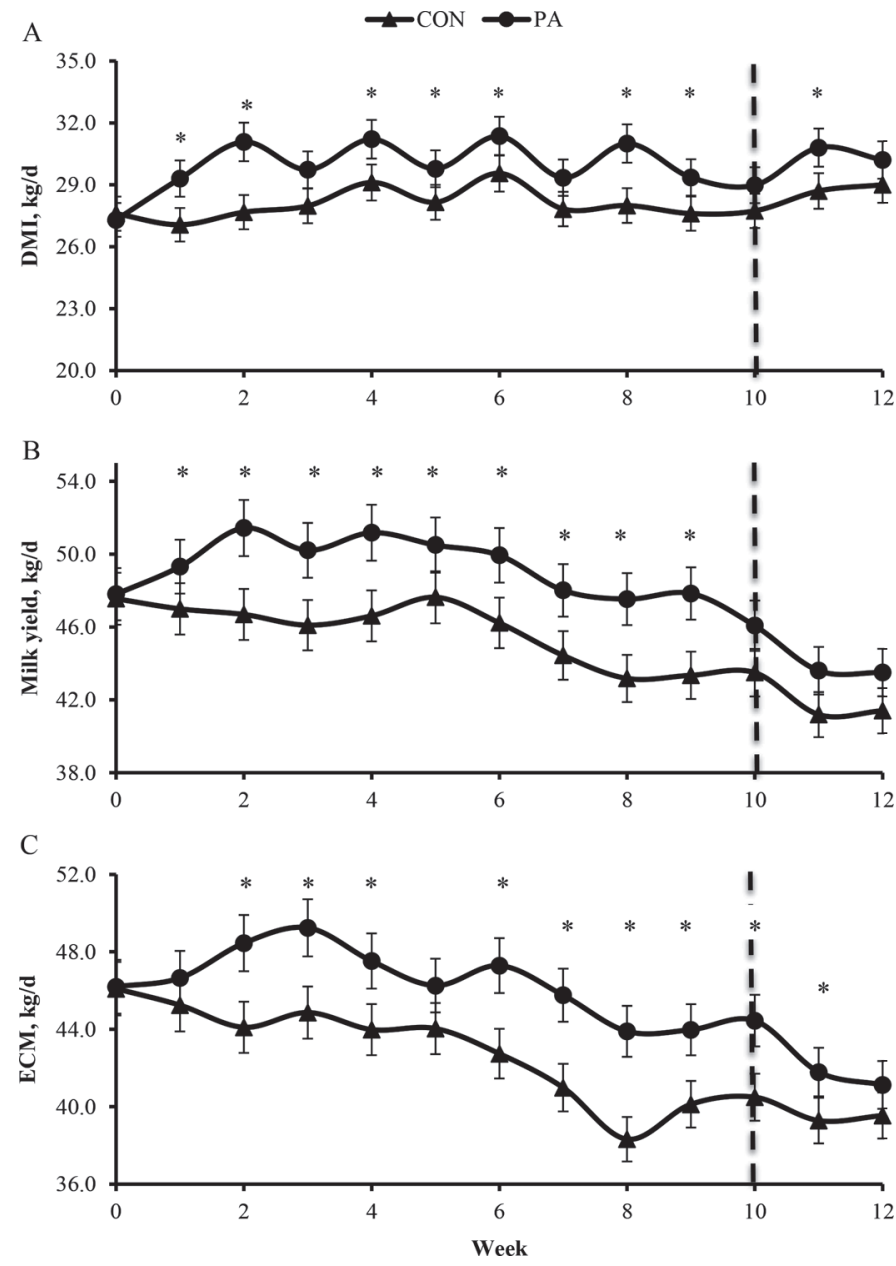

Figure 1. Effects of dietary treatments on DMI (A), milk yield (B), and ECM $(\mathrm{C})$ over time during the treatment and carryover periods. Treatments were a control diet (CON) and a diet supplemented with $1.5 \%$ of C16:0-enriched fatty acid supplement replacing soyhulls (PA). The dashed line at wk 10 indicates the start of the carryover period, when all cows were fed a common diet with no supplemental fat added. Treatment by time interaction was observed for milk yield $(P=0.03)$, and a tendency for an interaction between treatment and time was observed for DMI $(P=0.15)$ and ECM $(P=0.13)$. ${ }^{*}$ Treatments differ $(P<0.05)$ within week. Error bars indicate SEM. change (interaction $P=0.09$ ), due to $\mathrm{PA}$ increasing $\mathrm{BW}$ change in primiparous but not in multiparous cows compared with CON (Figure 2F).

We examined short-term (2 wk) carryover effects of treatments on production responses (Supplemental Table S1; https://doi.org/10.3168/jds.2017-13946). During the carryover period, PA tended to increase FCM $(P=0.06)$, ECM $(P=0.07)$, and milk fat yield $(P=0.07)$ compared with CON. We observed interactions between treatment and parity for milk yield $(P=$ $0.10)$, FCM $(P=0.04), \operatorname{ECM}(P=0.08)$, and fat yield $(P=0.03)$, due to PA increasing these variables to a greater extent in multiparous than primiparous cows (Supplemental Figure S1; https://doi.org/10.3168/jds .2017-13946).

\section{Milk Fatty Acid Yield and Concentration}

Milk FA are derived from 2 sources: $<16$ carbon FA from de novo synthesis in the mammary gland and $>16$ carbon FA originating from extraction from plasma. Mixed-source FA (C16:0 and cis-9 C16:1) originate from de novo synthesis in the mammary gland and extraction from plasma. Compared with $\mathrm{CON}$, PA reduced de novo FA concentration $(P<0.01$; Table 3$)$ and tended to reduce preformed FA concentration $(P$ $=0.08)$, but increased mixed source FA $(P<0.01)$. On a yield basis, $\mathrm{PA}$ increased mixed source $\mathrm{FA}(P<0.01$; Table 3 ) primarily due to the increase in concentration and yield of C16:0 $(P<0.01$; Supplemental Tables S2 and S3; https://doi.org/10.3168/jds.2017-13946). No treatment differences were observed for the yield of de novo $(P=0.37)$ and preformed FA $(P=0.84)$. Additionally, PA increased the yield of $\mathrm{C} 4: 0(P=0.04)$ and tended to increase the yield of cis-9 C18:1 $(P=$ 0.10; Supplemental Table S3; https://doi.org/10.3168/ jds.2017-13946) compared with CON. We observed an interaction between treatment and parity for de novo FA yield (interaction $P=0.07$ ) due to $\mathrm{PA}$ increasing de novo FA yield in primiparous but not in multiparous cows (Figure 3A). In contrast, PA increased mixed FA yield to a greater extent in multiparous than primiparous cows (interaction $P=0.08$; Figure $3 \mathrm{~B}$ ). We observed an interaction between treatment and parity for preformed milk FA yield $(P=0.01)$ due to PA reducing preformed FA yield in primiparous cows but increasing it in multiparous cows (Figure 3C).

\section{Plasma Metabolites}

Compared with CON, PA increased plasma concentration of nonesterified fatty acids (NEFA; $P=0.02$; Table 4$)$, did not affect BHB $(P=0.49)$, and tended to increase plasma concentration of insulin $(P=0.10)$. 
We observed an interaction between treatment and parity for plasma insulin due to PA increasing insulin in primiparous but not in multiparous cows (Figure 3F). A tendency for an interaction between treatment and parity was observed for NEFA $(P=0.12)$ due to PA increasing plasma NEFA in multiparous but not in primiparous cows (Figure 3D). Similarly, we observed a tendency for an interaction between treatment and parity for plasma BHB $(P=0.15)$ due to PA decreasing $\mathrm{BHB}$ in multiparous but not in primiparous cows (Figure 3E).

\section{Nutrient Digestibility}

No difference in NDF intake was observed between treatments $(P=0.17$; Table 5$)$. Compared with CON, PA increased DM and NDF digestibilities (both $P<$ $0.01)$. Although PA did not affect 18-carbon FA digestibility $(P=0.79)$, PA decreased 16 -carbon and total FA digestibilities (both $P<0.01$ ). Compared with $\mathrm{CON}$, PA increased absorbed total FA by $316 \mathrm{~g} / \mathrm{d}(P<0.01)$, absorbed 16-carbon FA by $187 \mathrm{~g} / \mathrm{d}(P<0.01)$, and absorbed 18-carbon FA by $75 \mathrm{~g} / \mathrm{d}(P<0.01)$.
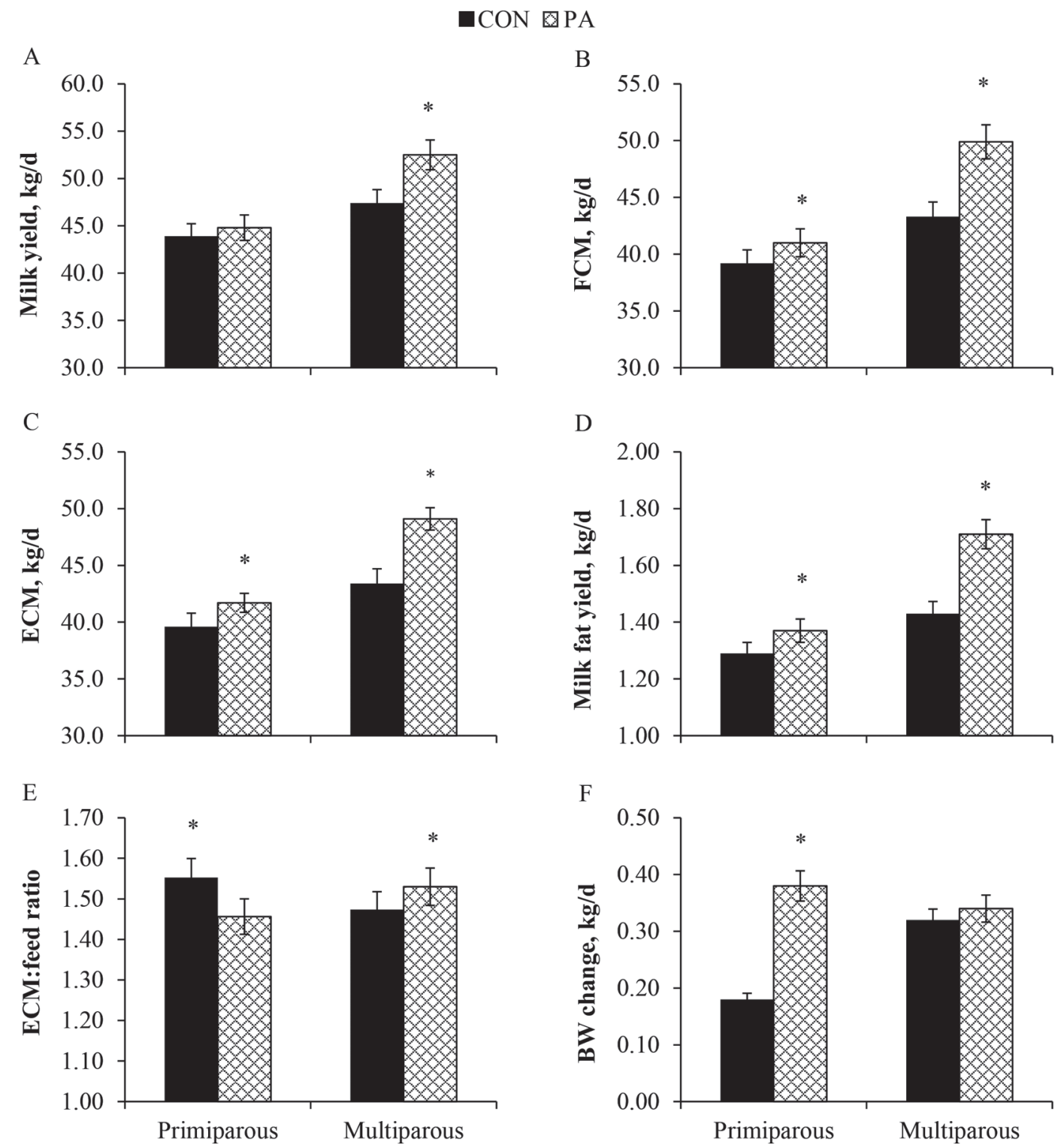

Figure 2. Effects of dietary treatments on milk yield (A), FCM (B), ECM (C) milk fat yield (D), ECM:feed ratio (E), and BW change (F) of primiparous and multiparous cows during the treatment period. Treatments were a control diet (CON) and a diet supplemented with $1.5 \%$ of C16:0-enriched fatty acid supplement replacing soyhulls (PA). Treatment by parity interaction was observed for $3.5 \% \mathrm{FCM}(P=0.04), \mathrm{ECM}(P$ $=0.05)$, milk fat yield $(P=0.05)$, ECM:feed ratio $(P<0.01)$, and BW change $(P=0.09)$, and a tendency for an interaction between treatment and parity was observed for milk yield $(P=0.15)$. ${ }^{*}$ Treatments differ $(P<0.05)$ within parity. Error bars indicate SEM. 
We observed an interaction between treatment and parity for total and 16-carbon absorbed FA (both $P<$ 0.01 ), due to PA increasing these to a greater extent in multiparous than primiparous cows (Supplemental Figure S2; https://doi.org/10.3168/jds.2017-13946). Additionally, compared with CON, PA increased absorbed 18-carbon FA in multiparous cows but not in primiparous cows (interaction $P=0.02$ ).

\section{Energy Calculations}

Compared with CON, PA increased apparent intake of DE $(P<0.01$; Table 6$), \mathrm{ME}(P<0.01), \mathrm{NE}_{\mathrm{L}}(P$ $<0.01)$, and dietary $\mathrm{NE}_{\mathrm{L}}$ concentration $(P<0.01)$. Additionally, compared with CON, PA increased milk energy output $(P<0.01)$, energy output in body reserves $(P=0.05)$, and energy partitioned to body reserves $(P=0.04)$, and decreased energy partitioned to maintenance $(P<0.01)$.

We observed an interaction between treatment and parity for milk energy output (interaction $P=0.10$ ) due to PA increasing milk energy output to a greater extent in multiparous than primiparous cows (Figure $4 \mathrm{~A})$. In contrast, an interaction between treatment and parity was observed for energy output in body reserves (interaction $P=0.10$ ) due to $\mathrm{PA}$ increasing energy output in body reserves in primiparous but not in multiparous cows compared with CON (Figure 4B). When considering energy partitioning (as \% of energy intake), a tendency for an interaction between treatment and parity was observed for energy partitioned to milk (interaction $P=0.11$ ) due to $\mathrm{PA}$ increasing energy partitioned to milk in multiparous but not in primiparous cows (Figure 4C). Compared with CON, PA increased energy partitioning toward body reserves in primiparous but not in multiparous cows (interaction $P=0.07$; Figure $4 \mathrm{D})$.

\section{DISCUSSION}

Previous research has showed that C16:0-enriched supplements increase the yield of milk fat and ECM in postpeak cows. However, our research, and work by others, has mostly evaluated production and metabolic responses during short-term feeding (maximum of 21-d feeding periods). This raises a question about the consistency of the response under long-term conditions. Also, previous studies have not evaluated potential interactions with parity so that we cannot accurately answer if parity would affect the response to C16:0 supplementation. Our study was therefore designed to evaluate the effects of feeding a C16:0-enriched supplement under long-term feeding conditions and potentially its interaction with parity on production responses of dairy cows.

Although most studies have reported that DMI has not been affected when C16:0-enriched supplements were fed compared with nonsupplemented control diets (e.g., de Souza et al., 2016, 2017b; Mathews et al., 2016) other have reported that DMI increased (Mosley et al., 2007) or decreased (Lock et al., 2013; Rico et al., 2014a) when these supplements were fed. In our study, although we observed variations in DMI across the 10 wk of supplementation, PA increased DMI compared with $\mathrm{CON}$ by $1.9 \mathrm{~kg} / \mathrm{d}$. One possible explanation for this increase in DMI is the fact that we conducted this study during the summer. Under heat-stress conditions, supplemental fat increases the ration energy density without substantially increasing the heat increment of fermentation, and may result in increased nutrient and

Table 3. Fatty acid (FA) concentration and yield ${ }^{1}$ by source of milk FA for cows fed treatment diets $(\mathrm{n}=39)$

\begin{tabular}{|c|c|c|c|c|c|c|c|c|c|c|}
\hline \multirow[b]{2}{*}{ Variable } & \multicolumn{2}{|c|}{ Treatment $^{2}$} & \multirow[b]{2}{*}{ SEM } & \multicolumn{7}{|c|}{$P$-value ${ }^{3}$} \\
\hline & $\mathrm{CON}$ & PA & & Treat & Par & Time & $\begin{array}{l}\text { Treat } \\
\times \text { Par }\end{array}$ & $\begin{array}{l}\text { Treat } \\
\times \text { time }\end{array}$ & $\begin{array}{c}\text { Par } \\
\times \text { time }\end{array}$ & $\begin{array}{c}\text { Treat } \times \text { Par } \\
\quad \times \text { time }\end{array}$ \\
\hline \multicolumn{11}{|c|}{ Summation by source, ${ }^{4} \mathrm{~g} / 100 \mathrm{~g}$ of FA } \\
\hline De novo & 25.4 & 21.5 & 0.49 & $<0.01$ & 0.07 & 0.02 & 0.21 & 0.01 & 0.12 & 0.39 \\
\hline Mixed & 33.7 & 39.6 & 0.53 & $<0.01$ & 0.38 & $<0.01$ & 0.61 & 0.52 & 0.29 & 0.27 \\
\hline Preformed & 40.8 & 38.9 & 0.77 & 0.08 & 0.07 & $<0.01$ & 0.65 & 0.15 & 0.05 & 0.79 \\
\hline \multicolumn{11}{|c|}{ Summation by source, ${ }^{4} \mathrm{~g} / \mathrm{d}$} \\
\hline De novo & 342 & 318 & 20.2 & 0.37 & 0.01 & $<0.01$ & 0.07 & 0.53 & 0.77 & 0.37 \\
\hline Mixed & 453 & 592 & 30.3 & $<0.01$ & 0.01 & $<0.01$ & 0.08 & 0.75 & 0.91 & 0.47 \\
\hline Preformed & 549 & 565 & 23.2 & 0.84 & 0.09 & $<0.01$ & 0.01 & 0.55 & 0.71 & 0.07 \\
\hline
\end{tabular}

${ }^{1}$ Milk samples collected at d 21, 42, and 63 of treatment period.

${ }^{2} \mathrm{CON}=$ control diet; $\mathrm{PA}=1.5 \%$ of $\mathrm{C} 16: 0$-enriched fatty acid supplement replacing soyhulls.

${ }^{3} P$-values refer to the ANOVA results for the main effects of treatment (Treat), parity (Par), time, and their interactions.

${ }^{4}$ De novo FA originate from mammary de novo synthesis ( $<16$ carbons), preformed FA originate from extraction from plasma ( $>16$ carbons), and mixed FA originate from both sources (C16:0 plus cis-9 C16:1). Concentrations and yields of individual fatty acids are reported in Supplemental Tables S2 and S3 (https://doi.org/10.3168/jds.2017-13946), respectively. 
$\square \mathrm{CON} \square \mathrm{PA}$
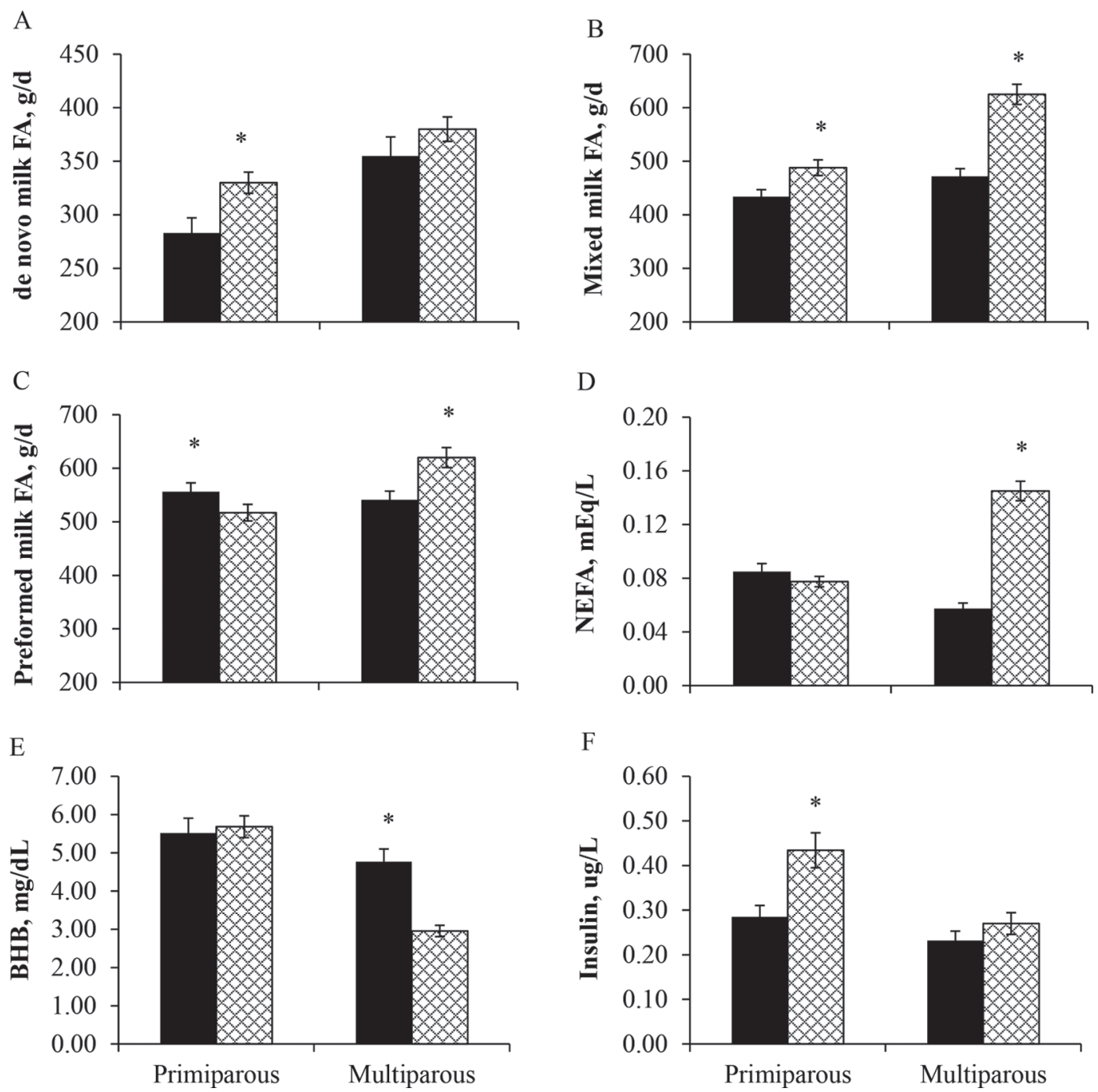

Figure 3. Effects of dietary treatments on de novo milk fatty acids (FA; A), mixed milk FA (B), preformed milk FA (C), and concentrations of plasma nonesterified fatty acids (NEFA; D), plasma BHB (E), and plasma insulin (E) of primiparous and multiparous cows during the treatment period. Treatments were a control diet $(\mathrm{CON})$ and a diet supplemented with $1.5 \%$ of C16:0-enriched FA supplement replacing soyhulls (PA). Treatment by parity interaction was observed for de novo milk FA $(P=0.07)$, mixed $(P=0.08)$, preformed $(P<0.01)$, and plasma insulin $(P=0.10)$, and a tendency for an interaction between treatment and parity was observed for NEFA $(P=0.12)$ and BHB $(P=0.15)$. *Treatments differ $(P<0.05)$ within parity. Error bars indicate SEM.

Table 4. Blood metabolite concentrations ${ }^{1}$ for cows fed treatment diets $(\mathrm{n}=39)$

\begin{tabular}{|c|c|c|c|c|c|c|c|c|c|c|}
\hline Variable & \multicolumn{2}{|c|}{ Treatment $^{2}$} & SEM & \multicolumn{7}{|c|}{$P$-value ${ }^{3}$} \\
\hline $\mathrm{BHB}, \mathrm{mg} / \mathrm{dL}$ & 5.14 & 4.31 & 0.82 & 0.49 & 0.41 & 0.42 & 0.15 & 0.39 & 0.45 & 0.56 \\
\hline Insulin, $\mu \mathrm{g} / \mathrm{L}$ & 0.27 & 0.36 & 0.03 & 0.10 & 0.46 & 0.01 & 0.10 & 0.35 & 0.45 & 0.22 \\
\hline
\end{tabular}

${ }^{1}$ Blood samples collected at d 21, 42, and 63 of treatment period.

${ }^{2} \mathrm{CON}=$ control diet; $\mathrm{PA}=1.5 \%$ of $\mathrm{C} 16: 0$-enriched fatty acid supplement replacing soyhulls.

${ }^{3} P$-values refer to the ANOVA results for the main effects of treatment (Treat), parity (Par), time, and their interactions.

${ }^{4} \mathrm{NEFA}=$ nonesterified fatty acids. 
Table 5. Intake and total-tract nutrient digestibility ${ }^{1}$ for cows fed treatment diets $(\mathrm{n}=39)$

\begin{tabular}{|c|c|c|c|c|c|c|}
\hline \multirow[b]{2}{*}{ Variable } & \multicolumn{2}{|c|}{ Treatment $^{2}$} & \multirow[b]{2}{*}{ SEM } & \multicolumn{3}{|c|}{$P$-value ${ }^{3}$} \\
\hline & $\mathrm{CON}$ & $\mathrm{PA}$ & & Treat & Par & Treat $\times$ Par \\
\hline \multicolumn{7}{|l|}{ Intake, $\mathrm{kg} / \mathrm{d}$} \\
\hline NDF & 8.93 & 8.98 & 0.19 & 0.17 & $<0.01$ & 0.43 \\
\hline \multicolumn{7}{|l|}{ Intake, $\mathrm{g} / \mathrm{d}$} \\
\hline Total FA ${ }^{4}$ & 1,019 & 1,489 & 33.6 & $<0.01$ & 0.02 & 0.27 \\
\hline 16-Carbon FA & 225 & 548 & 16.4 & $<0.01$ & 0.03 & 0.16 \\
\hline 18-Carbon FA & 797 & 886 & 17.9 & $<0.01$ & 0.01 & 0.19 \\
\hline \multicolumn{7}{|l|}{ Digestibility, \% } \\
\hline $\mathrm{DM}$ & 62.3 & 65.6 & 0.77 & $<0.01$ & $<0.01$ & 0.43 \\
\hline $\mathrm{NDF}$ & 40.4 & 45.4 & 1.27 & $<0.01$ & $<0.01$ & 0.79 \\
\hline Total FA & 81.9 & 77.5 & 1.04 & $<0.01$ & 0.67 & 0.17 \\
\hline 16-Carbon FA & 79.8 & 68.9 & 1.67 & $<0.01$ & 0.12 & 0.35 \\
\hline 18-Carbon FA & 83.7 & 84.1 & 0.91 & 0.79 & 0.39 & 0.85 \\
\hline \multicolumn{7}{|c|}{ Absorbed FA, g/d } \\
\hline Total FA & 833 & 1,149 & 28.9 & $<0.01$ & $<0.01$ & $<0.01$ \\
\hline 16-Carbon FA & 187 & 374 & 15.8 & $<0.01$ & 0.26 & $<0.01$ \\
\hline 18-Carbon FA & 667 & 742 & 15.8 & $<0.01$ & $<0.01$ & 0.02 \\
\hline
\end{tabular}

${ }^{1}$ Fecal samples collected at $\mathrm{d} 63$ of the treatment period.

${ }^{2} \mathrm{CON}=$ control diet; $\mathrm{PA}=1.5 \%$ of $\mathrm{C} 16: 0$-enriched fatty acid supplement replacing soyhulls.

${ }^{3} P$-values refer to the ANOVA results for the main effects of treatment (Treat), parity (Par), and their interaction.

${ }^{4} \mathrm{FA}=$ fatty acids.

energy availability for milk production (Wang et al., 2010). Our experiment was not designed to evaluate C16:0 supplementation under heat-stress conditions, but we cannot rule out the possibility that these results are associated with environment conditions. In addition, we observed that PA increased both NDF and

Table 6. Calculated energy values and energy partitioning for cows fed treatment diets $(\mathrm{n}=39)$

\begin{tabular}{|c|c|c|c|c|c|c|}
\hline \multirow[b]{2}{*}{ Variable } & \multicolumn{2}{|c|}{ Treatment $^{1}$} & \multirow[b]{2}{*}{ SEM } & \multicolumn{3}{|c|}{$P$-value ${ }^{2}$} \\
\hline & $\mathrm{CON}$ & $\mathrm{PA}$ & & Treat & Par & Treat $\times$ Par \\
\hline \multicolumn{7}{|c|}{ Apparent energy intake, ${ }^{3} \mathrm{Mcal} / \mathrm{d}$} \\
\hline $\mathrm{DE}^{4}$ & 80.1 & 89.0 & 2.04 & $<0.01$ & $<0.01$ & 0.19 \\
\hline $\mathrm{ME}^{5}$ & 68.0 & 76.4 & 1.85 & $<0.01$ & $<0.01$ & 0.19 \\
\hline $\mathrm{NE}_{\mathrm{L}}^{6}$ & 42.3 & 48.0 & 1.21 & $<0.01$ & $<0.01$ & 0.20 \\
\hline $\mathrm{NE}_{\mathrm{L}}{ }^{7} \mathrm{~kg} / \mathrm{DMI}$ & 1.53 & 1.62 & 0.02 & $<0.01$ & $<0.01$ & 0.24 \\
\hline \multicolumn{7}{|c|}{ Energy output, Mcal/d } \\
\hline Milk $^{8}$ & 29.1 & 33.2 & 1.02 & $<0.01$ & 0.03 & 0.10 \\
\hline Body reserves ${ }^{9}$ & 1.58 & 2.24 & 0.31 & 0.05 & 0.59 & 0.10 \\
\hline Maintenance $^{10}$ & 11.6 & 12.5 & 0.98 & 0.45 & $<0.01$ & 0.22 \\
\hline \multicolumn{7}{|c|}{ Partitioning, $\%$ energy intake } \\
\hline Milk & 68.7 & 69.2 & 0.45 & 0.10 & 0.65 & 0.11 \\
\hline Body reserves & 3.72 & 4.75 & 0.26 & 0.04 & 0.25 & 0.07 \\
\hline Maintenance & 27.5 & 26.0 & 0.35 & $<0.01$ & 0.72 & 0.20 \\
\hline
\end{tabular}

${ }^{1} \mathrm{CON}=$ control diet; $\mathrm{PA}=1.5 \%$ of $\mathrm{C} 16: 0$-enriched fatty acid supplement replacing soyhulls.

${ }^{2} P$-values refer to the ANOVA results for the main effects of treatment (Treat), parity (Par), and their interaction.

${ }^{3}$ Apparent energy intake values determined based on digestibility measurements during wk 9 of supplementation.

${ }^{4} \mathrm{DE}=$ digestible energy intake: gross energy intake $(\mathrm{Mcal} / \mathrm{d}) \times$ gross energy digestibility.

${ }^{5} \mathrm{ME}$ intake was calculated from DE according to NRC (2001).

${ }^{6} \mathrm{NE}_{\mathrm{L}}$ intake was calculated from DE through ME according to NRC (2001).

${ }^{7} \mathrm{NE}_{\mathrm{L}}$ intake/DMI.

${ }^{8}$ Milk $\mathrm{NE}_{\mathrm{L}}(\mathrm{Mcal} / \mathrm{d})=$ milk yield $(\mathrm{kg} / \mathrm{d}) \times[($ fat $\% \times 0.0929)+($ true protein $\% \times 0.0563)+($ lactose $\% \times$ 0.0395)] (NRC, 2001).

${ }^{9}$ Body reserves $(\mathrm{Mcal} / \mathrm{d})=[(2.88+1.036 \times \mathrm{BCS}) \times \Delta \mathrm{BW}]$, where BCS was the average BCS for study and $\triangle \mathrm{BW}$ was $\mathrm{BW}$ change.

${ }^{10} \mathrm{NE}_{\mathrm{L}}$ maintenance $(\mathrm{Mcal} / \mathrm{d})=\mathrm{NE}_{\mathrm{L}}$ intake $(\mathrm{Mcal} / \mathrm{d})-\operatorname{milk} \mathrm{NE}_{\mathrm{L}}(\mathrm{Mcal} / \mathrm{d})-\mathrm{NE}_{\mathrm{L}}$ reserves $(\mathrm{Mcal} / \mathrm{d})$. 
DM digestibility compared with CON. The observed increase in NDF digestibility is in agreement with previous studies feeding C16:0-enriched supplements (Piantoni et al., 2013; de Souza et al., 2017b; Rico et al., 2017). The increase in NDF digestibility may be associated with an increase in retention time driven by an increase in CCK secretion (Piantoni et al., 2013) or the lower NDF content in our PA treatment (de Souza et al., 2017b). Increasing the intake of NDF from nonforage fiber sources such as soyhulls may decrease total-tract NDF digestibility due to shifting NDF digestion to the hindgut (Firkins, 1997). Alternatively, bacteria typically synthesize C16:0 de novo to produce phosphatidic acid, the precursor for FA components in membranes of Butyrivibrio bacteria (Hackmann and Firkins, 2015). However, if dietary C16:0 could be incorporated into rumen bacterial membranes, considerable ATP would be spared, which may favor bacterial growth (Vlaeminck et al., 2006), potentially increasing NDF digestibility. Vargas-Bello-Pérez et al. (2016) observed that a diet supplemented with hydrogenated palm oil (47\% C16:0 and 43\% C18:0) increased ruminal total bacteria measured as copies of $16 \mathrm{~S}$ ribosomal DNA compared with a nonsupplemented control diet and soybean oil-supplemented diet, indicating potential role of the FA profile of supplemental fat on rumen microbes. Although the exact mechanisms for the increase in NDF digestibility with C16:0 supplementation are unknown, this topic deserves future research.

Although Rico et al. (2014a) reported that feeding a C16:0-enriched supplement had positive effects on 16-carbon and total FA digestibilities of low-producing cows, other studies with higher producing cows have observed reductions in FA digestibility when feeding similar supplements (Piantoni et al., 2013; de Souza et al., 2017a). In our study, we observed that compared with CON, PA reduced the digestibility of 16-carbon and total FA. In a recent meta-analysis Boerman et al. (2015a) observed no reduction in FA digestibility when the duodenal flow of C16:0 increased up to 500

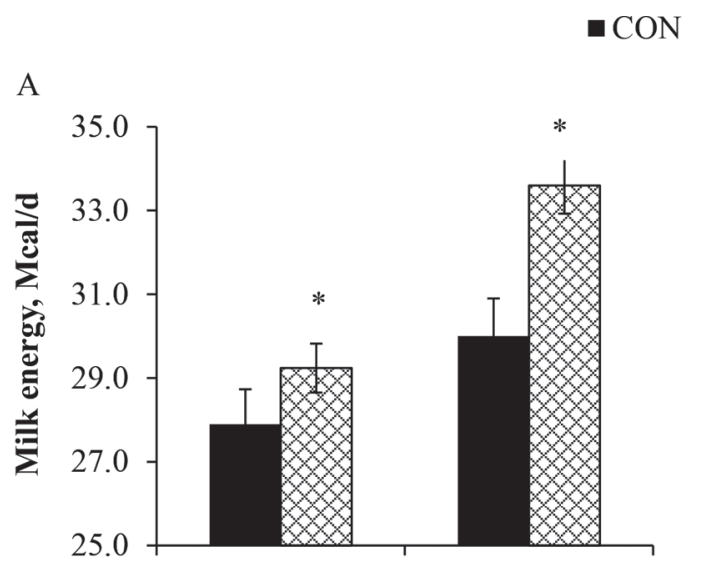

PA
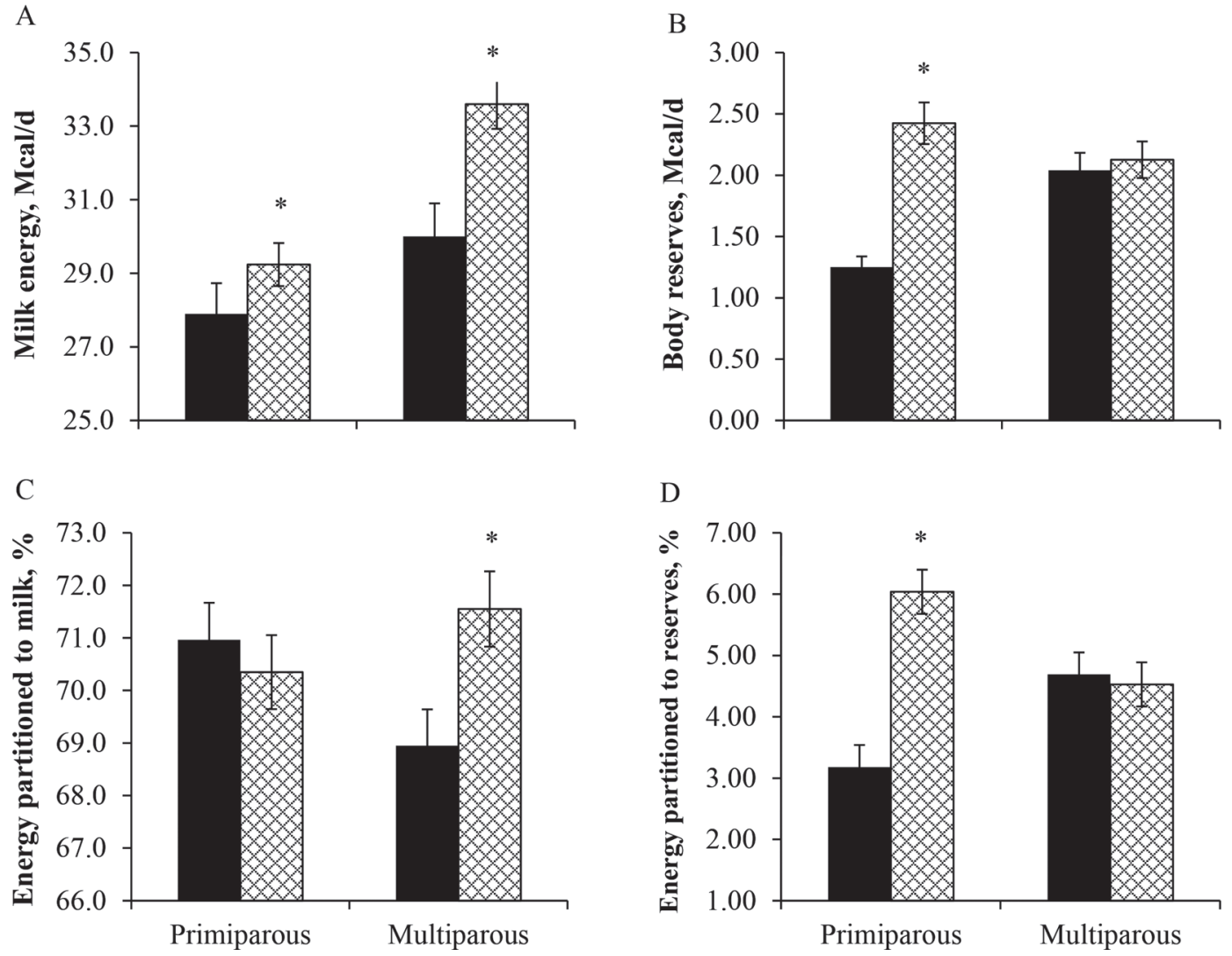

Figure 4. Effects of dietary treatments on milk energy output (A), energy in body reserves (B), energy partitioned to milk (C), and energy partitioned to body reserves (D) of primiparous and multiparous cows. Treatments were a control diet (CON) and a diet supplemented with 1.5\% of C16:0-enriched fatty acid supplement replacing soyhulls (PA). Treatment by parity interaction was observed for milk energy output $(P$ $=0.10)$, energy in body reserves $(P=0.10)$, energy partitioned to body reserves $(P=0.07)$, and a tendency for an interaction between treatment and parity was observed for milk energy partitioning $(P=0.11)$. ${ }^{*}$ Treatments differ $(P<0.05)$ within parity. Error bars indicate SEM. 
$\mathrm{g} / \mathrm{d}$, whereas increasing the duodenal flow of C18:0 to the same level reduced FA digestibility. Whereas total flow of FA at the duodenum affects FA digestibility (Boerman et al., 2015a), the profile of FA entering the duodenum is a critical factor affecting FA digestibility (Doreau and Chilliard, 1997). In our study, although the intake of 16-carbon FA was slightly over $500 \mathrm{~g} / \mathrm{d}$ for PA and we observed that PA reduced FA digestibility, this reduction was similar to that observed by de Souza et al. (2017b) and lower than that reported by Piantoni et al. (2013). Reasons for these differences might include the greater prill size $(890 \pm 140 \mu \mathrm{m})$ and content of C16:0 (99\% C16:0) used by Piantoni et al. (2013) compared with our current study. Although the exact mechanisms for the reduction in FA digestibility as FA intake increases are unknown, potential causes have been suggested and include competition for absorption sites and limits in emulsification (Drackley, 2000). Due to the increase in DMI and DM digestibility, we also observed that PA increased energy intake including DE, $\mathrm{ME}$, and $\mathrm{NE}_{\mathrm{L}}$. Unfortunately, energy intake is generally predicted from the diet and not actually measured in previous experiments. Considering how variable DM digestibility among cows can be (Piantoni et al., 2013), predicting energy values using energy concentrations predicted from dietary composition has limited application (Piantoni et al., 2015).

Milk production response to C16:0 supplementation in short-term studies have been inconsistent with some studies reporting no effect of C16:0-enriched supplements on milk yield (Lock et al., 2013; Rico et al., 2014a), whereas others have reported increases in milk yield when these supplements were fed (Mosley et al., 2007; Piantoni et al., 2013). In our study, PA increased milk yield by $3.8 \mathrm{~kg} / \mathrm{d}$ compared with CON over the 10 -wk supplementation period. Similarly, when compared with a nonsupplemented control diet, Mosley et al. (2007) observed an increase of $3.3 \mathrm{~kg} / \mathrm{d}$ of milk in cows consuming a diet containing alfalfa silage and supplemented with a C16:0-enriched supplement ( $>808$ $\mathrm{g} / \mathrm{d}$ of C16:0). Likewise, Mathews et al. (2016) reported an increase in milk yield of $3.4 \mathrm{~kg} / \mathrm{d}$ in cows supplemented with $\mathrm{C} 16: 0$ ( $\sim 85 \% \mathrm{C} 16: 0 ; 3.9 \%$ diet $\mathrm{DM})$ over a 7 -wk period. In our study, the increase in milk yield was driven by the effects of PA mainly on multiparous cows because we observed a tendency for a treatment by parity interaction due to PA increasing milk yield in multiparous but not primiparous cows. These results agree with our initial hypothesis where we postulated that the production responses of multiparous cows would be greater than primiparous cows due to their additional requirement for growth. The lactation curve of primiparous cows is flatter than that of multiparous cows, which may indicate that they are less responsive to interventions that affect lactogenesis (Akers, 2002; Miller et al., 2006). Also, when comparing mammary cell dynamics of primiparous versus multiparous cows, the extent of mammary cell differentiation was lower in primiparous than multiparous cows (Miller et al., 2006). Additionally, potential hormonal changes (i.e., concentration of IGF-1, leptin, and insulin) between primiparous and multiparous cows may affect tissue mobilization and nutrient partitioning into adipose tissue as well as mammary gland during the first lactation (Tucker, 2000; Wathes et al., 2007). Therefore, the lower milk production response to PA supplementation in primiparous cows may be associated with differences in mammary metabolism and priority of nutrient partitioning to other tissues.

We observed that PA increased energy partitioned to milk, but the response varied according to parity. The interaction between treatment and parity for milk energy output was due to PA increasing ECM to a greater extent in multiparous than primiparous cows. The increase in ECM was consistent throughout the 10 wk of PA supplementation. Similarly, previous studies have observed that C16:0 supplementation increased ECM (Piantoni et al., 2013; Lock et al., 2013; de Souza et al., 2018). Most of our short-term studies involving C16:0-enriched supplements (fed at 1.5 to $2.0 \%$ diet $\mathrm{DM}$ ) have indicated no changes in $\mathrm{BW}$ and $\mathrm{BCS}$ compared with nonfat control diets (Piantoni et al., 2013; Lock et al., 2013; de Souza et al., 2018). Interestingly, an interaction between treatment and parity was observed for energy output in body reserves, which was driven by PA increasing BW gain in primiparous but did not change BW gain in multiparous cows compared with CON. Primiparous cows usually partition more nutrients to body reserves and growth during their first lactation compared with multiparous cows (Tucker, 2000). This difference in nutrient partitioning is probably driven by insulin, as we observed that PA increased plasma insulin concentration in primiparous but not in multiparous cows. Elevated insulin concentrations would reduce plasma FA through inhibiting lipolysis or increasing lipogenesis (Vernon, 2005). In addition, increased concentrations of plasma triglycerides could result from higher intake of dietary FA increasing the supply of triglyceride-rich lipoproteins available in circulation. As a result, increases in insulin could partition circulating FA in triglycerides into adipose instead of uptake by the mammary gland and reduce lipolysis from adipose tissues. It is important to point out that we measured BW 3 times per wk, which likely improved the accuracy of our measurements compared with studies that only measured BW at the beginning and end of a study. Understanding the mechanisms involved with the increase in insulin due 
to PA supplementation in primiparous cows deserves further attention.

We evaluated the potential short-term carryover effect of C16:0 supplementation on production responses. The PA treatment tended to increase the yield of FCM, ECM, and milk fat. Also, the carryover effect tended to be greater in multiparous than primiparous cows. Similarly, Mathews et al. (2016) reported a short-term carryover effect on milk fat yield and ECM when cows were supplemented with C16:0 ( $\sim 85 \%$ C16:0; $3.9 \%$ diet DM) over a 7 -wk period. Although some studies observed carryover effects of fat supplementation in early lactation (i.e., Piantoni et al., 2015; de Souza et al., 2017a), the carryover effect in postpeak cows has been examined less. Further studies are needed to understand factors associated with carryover effects and to determine the duration and magnitude of this under different dietary conditions.

We observed that PA consistently increased milk fat yield by $155 \mathrm{~g} / \mathrm{d}$ compared with CON over the 10-wk supplementation period. Most of our short-term studies involving C16:0-enriched supplements (fed at 1.5 to $2.0 \%$ diet $\mathrm{DM}$ ) have indicated increases in milk fat yield of $\sim 100$ g/d (Piantoni et al., 2013; Lock et al., 2013; de Souza et al., 2018). In long-term feeding, Mathews et al. (2016) observed that feeding a C16:0-enriched supplement $(3.9 \%$ diet $\mathrm{DM})$ over a 7 -wk period also increased milk fat yield by $\sim 200 \mathrm{~g} / \mathrm{d}$. Although Rico et al. (2017) observed that maximum milk fat yield response occurred when $\mathrm{C} 16: 0$ was fed at $1.5 \%$ of diet $\mathrm{DM}$, the incorporation of C16:0 into milk fat increased linearly as C16:0 dose increased. Overall, the increase in milk fat associated with our PA treatment occurred due to an increase in yield of 16-carbon milk FA (derived from both de novo synthesis and extraction from plasma), which is in agreement with several previous studies that fed C16:0-enriched supplements (e.g., Piantoni et al., 2013; Lock et al., 2013; de Souza et al., 2018). In addition, we observed an interaction between treatment and parity for milk fat yield due to PA increasing it to a greater extent in multiparous $(+240$ $\mathrm{g} / \mathrm{d})$ compared with primiparous $(+80 \mathrm{~g} / \mathrm{d})$ cows. This greater milk fat yield response was due to the greater increase in absorbed total FA and partitioning toward milk when PA was fed to multiparous compared with primiparous cows. Interestingly, we also observed interactions between treatment and parity for the source of milk FA. In multiparous cows, the increase in milk fat yield by PA was driven by an increase in the yield of mixed milk FA $(+140 \mathrm{~g} / \mathrm{d})$ and preformed milk FA $(+70 \mathrm{~g} / \mathrm{d})$. The major preformed FA increased by PA was cis-9 C18:1, which likely occurs as part of the mechanisms required to maintain milk fluidity (Jensen, 2002). In contrast, the increase in milk fat yield by PA in primiparous cows was due to an increase in the yield of de novo milk FA $(+50 \mathrm{~g} / \mathrm{d})$ and mixed milk FA $(+45$ $\mathrm{g} / \mathrm{d}$ ), and a reduction in the yield of preformed milk FA $(-25 \mathrm{~g} / \mathrm{d})$. The increase in de novo milk FA was driven by increases in the yield C4:0, C6:0, C8:0, C10:0, and $\mathrm{C} 14: 0$, whereas the increase in mixed was mainly a result of the increase in C16:0. These results may be due to differences in nutrient partitioning probably driven by insulin, as we observed that PA increased plasma insulin concentration in primiparous but not in multiparous cows. Supporting our results, Winkelman and Overton (2013) observed that cows receiving injections of long-acting insulin for $10 \mathrm{~d}$ changed milk FA profile by increasing the yield of de novo milk FA and reducing preformed milk FA.

\section{CONCLUSIONS}

Our results demonstrate that supplementation with C16:0 increases DMI, energy intake, milk yield, milk fat content and yield, and ECM in both multiparous and primiparous cows. Production responses to C16:0 were consistent throughout the 10-wk treatment period, and C16:0 supplementation interacted with parity, with production responses increased to a greater extent in multiparous than primiparous cows when C16:0 was fed. In addition, C16:0 supplementation increased BW change in primiparous cows but not in multiparous cows. When considering energy partitioning, we observed that C16:0 increased energy partitioned to milk in multiparous cows, and increased energy partitioned to body reserves in primiparous cows.

\section{ACKNOWLEDGMENTS}

We acknowledge the Michigan Alliance for Animal Agriculture and Energy Feeds International (Lago Vista, TX) for financial support of this study. We acknowledge C. L. Preseault, L. N. Worden, J. Guy, Y. Sun, S. Schmidt, and M. Western (all in the Department of Animal Science, Michigan State University, East Lansing), and the staff of the Michigan State University Dairy Cattle Teaching and Research Center for their assistance in this experiment. Jonas de Souza was supported by a $\mathrm{PhD}$ fellowship from Coordenação de Aperfoiçamento de Pessoal de Nivel Superior (CAPES) from the Brazilian Ministry of Education (Brasilia, DF, Brazil).

\section{REFERENCES}

Akers, R. M. 2002. Lactation and the Mammary Gland. Iowa State University Press, Ames.

AOAC. 1990. Official Methods of Analysis. Vol 2. 15th ed. AOAC Int., Arlington, VA. 
Boerman, J. P., J. L. Firkins, N. R. St-Pierre, and A. L. Lock. 2015a. Intestinal digestibility of long-chain fatty acids in lactating dairy cows: A meta-analysis and meta regression. J. Dairy Sci. 98:88898903.

Boerman, J. P., S. B. Potts, M. J. VandeHaar, and A. L. Lock. 2015b. Effects of partly replacing dietary starch with fiber and fat on milk production and energy partitioning. J. Dairy Sci. 98:7264-7276.

Cochran, R. C., D. C. Adams, J. D. Wallace, and M. L. Galyean. 1986. Predicting the digestibility of different diets with internal markers: Evaluation of four potential markers. J. Anim. Sci. 63:1476-1483.

de Souza, J., F. Batistel, and F. A. P. Santos. 2017a. Effect of sources of Ca salts of fatty acids on production, nutrient digestibility, energy balance, and carryover effects of early lactation grazing dairy cows. J. Dairy Sci. 100:1072-1085.

de Souza, J., J. L. Garver, C. L. Preseault, and A. L. Lock. 2017b. Effects of prill size of a palmitic acid-enriched fat supplement on yield of milk and milk components and nutrient digestibility of dairy cows. J. Dairy Sci. 100:379-384.

de Souza, J., C. L. Preseault, and A. L. Lock. 2016. Short communication: Lactational responses to palmitic acid supplementation when replacing soyhulls or dry ground corn. J. Dairy Sci. 99:1945-1950.

de Souza, J., C. L. Preseault, and A. L. Lock. 2018. Altering the ratio of dietary palmitic, stearic, and oleic acids in diets with or without whole cottonseed affects nutrient digestibility, energy partitioning, and production responses of dairy cows. J. Dairy Sci. 101:172-185.

Doreau, M., and Y. Chilliard. 1997. Digestion and metabolism of dietary fat in farm animals. Br. J. Nutr. 78(Suppl. 1):S15-S35.

Drackley, J. K. 2000. Lipid Metabolism. Pages 97-119 in Farm Animal Metabolism and Nutrition. J. P. F. D’Mello, ed. CABI Publishing, New York, NY.

Drackley, J. K., T. M. Cicela, and D. W. LaCount. 2003. Responses of primiparous and multiparous Holstein cows to additional energy from fat or concentrate during summer. J. Dairy Sci. 86:1306-1314.

Firkins, J. L. 1997. Effects of feeding nonforage fiber sources on site of fiber digestion. J. Dairy Sci. 80:1426-1437.

Grummer, R. R., P. C. Hoffman, M. L. Luck, and S. J. Bertics. 1995 Effect of prepartum and postpartum dietary energy on growth and lactation of primiparous cows. J. Dairy Sci. 78:172-180.

Hackmann, T. J., and J. L. Firkins. 2015. Electron transport phosphorylation in rumen butyrivibrios: Unprecedented ATP yield for glucose fermentation to butyrate. Front. Microbiol. 6:622. https:// doi.org/10.3389/fmicb.2015.00622.

Harvatine, K. J., and M. S. Allen. 2006. Effects of fatty acid supplements on milk yield and energy balance of lactating dairy cows. J. Dairy Sci. 89:1081-1091.

Holter, J. B., H. H. Hayes, and W. E. Urban Jr.. 1992. Energy balance and lactation response in Holstein cows supplemented with cottonseed with or without calcium soap. J. Dairy Sci. 75:1480-1494.

Jensen, R. G. 2002. The composition of bovine milk lipids: January 1995 to December 2000. J. Dairy Sci. 85:295-350.

Lock, A. L., C. L. Preseault, J. E. Rico, K. E. DeLand, and M. S. Allen. 2013. Feeding a C16:0-enriched fat supplement increased the yield of milk fat and improved feed efficiency. J. Dairy Sci. 96:6650-6659.

Mathews, A. T., J. E. Rico, N. T. Sprenkle, A. L. Lock, and J. W. McFadden. 2016. Increasing palmitic acid intake enhances milk production and prevents glucose-stimulated fatty acid disappearance without modifying systemic glucose tolerance in mid-lactation dairy cows. J. Dairy Sci. 99:8802-8816.

Miller, N., L. Delbecchi, D. Petitclerc, G. F. Wagner, B. G. Talbot, and P. Lacasse. 2006. Effect of stage of lactation and parity on mammary gland cell renewal. J. Dairy Sci. 89:4669-4677.
Mosley, S. A., E. E. Mosley, B. Hatch, J. I. Szasz, and A. Corato. 2007. Effect of varying levels of fatty acids from palm oil on feed intake and milk production in Holstein cows. J. Dairy Sci. 90:987-993.

NRC. 2001. Nutritional Requirements of Dairy Cattle. 7th rev. ed. Natl. Acad. Sci., Washington, DC.

Palmquist, D. L. 1994. The role of dietary fats in efficiency of ruminants. J. Nutr. 124:1377S-1382S.

Piantoni, P., A. L. Lock, and M. S. Allen. 2013. Palmitic acid increased yields of milk and milk fat and nutrient digestibility across production level of lactating cows. J. Dairy Sci. 96:7143-7154.

Piantoni, P., A. L. Lock, and M. S. Allen. 2015. Saturated fat supplementation interacts with dietary forage neutral detergent fiber content during the immediate postpartum period in Holstein cows: Energy balance and metabolism. J. Dairy Sci. 98:3323-3334.

Rabiee, A. R., K. Breinhild, W. Scott, H. M. Golder, E. Block, and I. J. Lean. 2012. Effect of fat additions to diets of dairy cattle on milk production and components: A meta-analysis and metaregression. J. Dairy Sci. 95:3225-3247.

Rico, D. E., Y. Ying, and K. J. Harvatine. 2014a. Effect of a highpalmitic acid fat supplement on milk production and apparent total-tract digestibility in high- and low-milk yield dairy cows. J. Dairy Sci. 97:3739-3751.

Rico, J. E., M. S. Allen, and A. L. Lock. 2014b. Compared with stearic acid, palmitic acid increased the yield of milk fat and improved feed efficiency across production level of cows. J. Dairy Sci. 97:1057-1066.

Rico, J. E., J. de Souza, M. S. Allen, and A. L. Lock. 2017. Nutrient digestibility and milk production responses to increasing levels of palmitic acid supplementation vary in cows receiving diets with or without whole cottonseed. J. Anim. Sci. 95:436-446.

Tucker, H. A. 2000. Hormone, mammary growth, and lactation: A 41year perspective. J. Dairy Sci. 83:874-884.

Van Soest, P. J., J. B. Robertson, and B. A. Lewis. 1991. Methods for dietary fiber, neutral detergent fiber, and nonstarch polysaccharides in relation to animal nutrition. J. Dairy Sci. 74:3583-3597.

Vargas-Bello-Pérez, E., N. Cancino-Padilla, J. Romero, and P. C. Garnsworthy. 2016. Quantitative analysis of ruminal bacterial populations involved in lipid metabolism in dairy cows fed different vegetable oils. Animal 10:1821-1828.

Vernon, R. G. 2005. Lipid metabolism during lactation: A review of adipose tissue-liver interactions and the development of fatty liver. J. Dairy Res. 72:460-469.

Vlaeminck, B., V. Fievez, A. J. R. Cabrita, A. J. M. Fonseca, and R. J. Dewhurst. 2006. Factors affecting odd- and branched-chain fatty acids in milk: A review. Anim. Feed Sci. Technol. 131:389-417.

Wang, J. P., D. P. Bu, J. Q. Wang, X. K. Huo, T. J. Guo, H. Y. Wei, L. Y. Zhou, R. R. Rastani, L. H. Baumgard, and F. D. Li. 2010. Effect of saturated fatty acid supplementation on production and metabolism indices in heat-stressed mid-lactation dairy cows. J. Dairy Sci. 93:4121-4127.

Wathes, D. C., Z. Cheng, N. Bourne, V. J. Taylor, M. P. Coffey, and S. Brotherstone. 2007. Differences between primiparous and multiparous dairy cows in the inter-relationships between metabolic traits, milk yield and body condition score in the periparturient period. Domest. Anim. Endocrinol. 33:203-225.

Wildman, E. E., G. M. Jones, P. E. Wagner, R. L. Boman, H. F Troutt Jr., and T. N. Lesch. 1982. A dairy cow body condition scoring system and its relationship to selected production characteristics. J. Dairy Sci. 65:495-501.

Winkelman, L. A., and T. R. Overton. 2013. Long-acting insulin alter milk composition and metabolism of lactating dairy cows. J. Dairy Sci. 96:7565-7577. 